\title{
Middle aortic syndrome: clinical and radiological findings
}

\author{
A Sumboonnanonda, B L Robinson, W M W Gedroyc, H M Saxton, J F Reidy, G B Haycock
}

Guy's Hospital, London, Department of Paediatrics

A Sumboonnanonda

G B Haycock

Department of Diagnostic Radiology

B L Robinson W $M$ W Gedroyc

H M Saxton

J F Reidy

Correspondence to: Professor G B Haycock UMDS, Division of Paediatrics, Floor 12,

Guy's Tower, Guy's Hospital, London Bridge,

London SE1 9RT.

Accepted 11 December 1991

\begin{abstract}
Eight patients with the middle aortic syndrome are described. They were aged 2 months to 14 years at diagnosis; follow up was one to 11 years. Clinical presentations included asymptomatic hypertension $(n=5)$, severe headache, nose bleed, and chest pain $(n=1)$, and cardiac failure $(n=1)$. All had severe hypertension requiring multiple drug treatment. Diminished peripheral pulses were not helpful in the diagnosis, which is made on aortography. Associated clinical findings were Williams' syndrome $(n=3)$ and appreciable eosinophilia $(n=3)$. The differential diagnosis includes Takayasu's arteritis, fibromuscular dysplasia, and neurofibromatosis. Blood pressure was adequately controlled by medical treatment in six patients. Surgical angioplasty was performed in two. One patient remained normotensive without drug treatment 21 months after operation; the other died of sepsis and uncontrollable haemorrhage in the postoperative period. Medical treatment is satisfactory in most cases: surgery should be reserved for those in whom blood pressure cannot be controlled without unacceptable side effects of drug treatment. Although rare, the middle aortic syndrome should be considered in the differential diagnosis of hypertension when commoner causes have been excluded. Aortography is necessary for diagnosis.
\end{abstract}

The middle aortic syndrome (MAS) is an uncommon condition and is characterised by severe narrowing of the abdominal aorta with involvement of the renal and visceral branches. It was first described by Sen et al in $1963 .{ }^{1}$ The disease is an important cause of hypertension in children and young adults, and is associated with a high morbidity and mortality. ${ }^{2}$ Several reports of the results of surgical and percutaneous transluminal angioplasty have appeared. ${ }^{3-6}$ It is evident from these that surgery is difficult and not always feasible and that transluminal angioplasty is usually ineffective. The treatment of choice is medical control of blood pressure in most patients, especially the very young.

The purpose of this paper is to review the clinical features, angiographic findings, associated diseases, and management in eight children with MAS diagnosed at Guy's Hospital between 1975 and 1988.

\section{Patients}

DEMOGRAPHIC FEATURES

Six of the eight patients included in the report were boys and two girls. The age range at diagnosis was 2 months to 14 years (mean $8 \cdot 3$ years). Five were white, two were Pakistani, and one was Egyptian. The perinatal history was unremarkable in all cases. There was no known history of an affected relative in any of the patients' families.

\section{CLINICAL FINDINGS}

There were no symptoms in five cases, hypertension having been discovered because blood

Table 1 Clinical features in MAS

\begin{tabular}{|c|c|c|c|c|c|c|c|c|}
\hline $\begin{array}{l}\text { Case } \\
\text { No }\end{array}$ & $\begin{array}{l}\text { Age at } \\
\text { diagnosis } \\
\text { (years) }\end{array}$ & Sex & $\begin{array}{l}\text { Racel } \\
\text { nationality }\end{array}$ & $\begin{array}{l}\text { Blood pressure } \\
\text { at diagnosis } \\
(\mathrm{mm} \mathrm{Hg})\end{array}$ & Other diagnoses & Treatment & $\begin{array}{l}\text { Follow up } \\
\text { (years) }\end{array}$ & Remarks \\
\hline 1 & $0 \cdot 2$ & $\mathbf{F}$ & Egyptian & $120 / 80$ & $\begin{array}{l}\text { Multiple congenital } \\
\text { abnormalities with } \\
\text { developmental delay }\end{array}$ & $\begin{array}{l}\text { Captopril, frusemide, } \\
\text { minoxidil }\end{array}$ & $1 \cdot 1$ & $\begin{array}{l}\text { TORCH screen and karyotype } \\
\text { normal. Normotensive at } \\
\text { follow up }\end{array}$ \\
\hline $\begin{array}{l}2 \\
3\end{array}$ & $\begin{array}{l}1 \cdot 3 \\
6 \cdot 8\end{array}$ & $\stackrel{\mathbf{M}}{\mathrm{F}}$ & $\begin{array}{l}\text { White } \\
\text { White }\end{array}$ & $\begin{array}{l}180 / ? \\
190 / 130\end{array}$ & Appreciable eosinophilia & $\begin{array}{l}\text { Frusemide, spironolactone } \\
\text { Surgical angioplasty and } \\
\text { autotransplant }\end{array}$ & $\begin{array}{l}2 \cdot 0 \\
1 \cdot 8\end{array}$ & $\begin{array}{l}\text { Hirsutism } \\
\text { Normotensive at follow up }\end{array}$ \\
\hline 4 & $6 \cdot 8$ & $\mathbf{M}$ & White & $170 / 130$ & Appreciable eosinophilia & $\begin{array}{l}\text { Captopril, frusemide, } \\
\text { amiloride, propranolol, } \\
\text { nifedipine, prazosin }\end{array}$ & $11 \cdot 0$ & $\begin{array}{l}\text { Hirsutism. Hypertensive } \\
\text { crisis after first aortogram. } \\
\text { Repeat aortogram: no } \\
\text { change at } 10 \text { years }\end{array}$ \\
\hline 5 & $11 \cdot 1$ & $\mathbf{M}$ & White & $160 / ?$ & $\begin{array}{l}\text { Williams' syndrome, } \\
\text { supravalvular aortic } \\
\text { stenosis, appreciable } \\
\text { eosinophilia }\end{array}$ & $\begin{array}{l}\text { Frusemide, amiloride, } \\
\text { atenolol }\end{array}$ & 1.5 & - \\
\hline 6 & $12 \cdot 4$ & $\mathbf{M}$ & Pakistani & Not recorded & $\begin{array}{l}\text { Williams' syndrome, } \\
\text { pulmonary stenosis, } \\
\text { developmental delay }\end{array}$ & $\begin{array}{l}\text { Surgical angioplasty and } \\
\text { autotransplant }\end{array}$ & 1 week & $\begin{array}{r}\text { Postoperative death } \\
\text { (sepsis, bleeding) }\end{array}$ \\
\hline 7 & $13 \cdot 8$ & $\mathbf{M}$ & Pakistani & $220 / 150$ & $\begin{array}{l}\text { Tuberculin test positive } \\
\text { (no history of } \mathrm{BCG} \text { ) }\end{array}$ & $\begin{array}{l}\text { Captopril, frusemide, } \\
\text { atenolol, nifedipine, } \\
\text { minoxidil }\end{array}$ & $3 \cdot 2$ & $\begin{array}{l}\text { Extensive extra-abdominal } \\
\text { arterial disease }\end{array}$ \\
\hline 8 & $14 \cdot 2$ & $\mathbf{M}$ & White & $160 / 90$ & $\begin{array}{l}\text { Williams' syndrome } \\
\text { hyperuricaemia? cause, } \\
\text { developmental delay }\end{array}$ & Bendrofluazide, atenolol & $\mathbf{0}$ & Lost to follow up \\
\hline
\end{tabular}


pressure was measured for incidental reasons. One patient presented with nose bleed, severe headache, and chest pain and another with cardiac failure. The clinical record was incomplete in the eighth case. Examination revealed severe hypertension in all, an ejection systolic murmur at the left sternal border in four, weak peripheral pulses in two, abdominal bruits in five, bilateral carotid and orbital bruits in one, and hypertensive retinopathy in two (table 1). Renal function was normal in five, impaired in one, and not recorded in two. The erythrocyte sedimentation rate (ESR) was normal in six and not recorded in two. Antinuclear antibodies were not detected in the five patients tested. Three patients had Williams' syndrome; two of these also had supravalvular aortic stenosis not requiring surgical treatment.
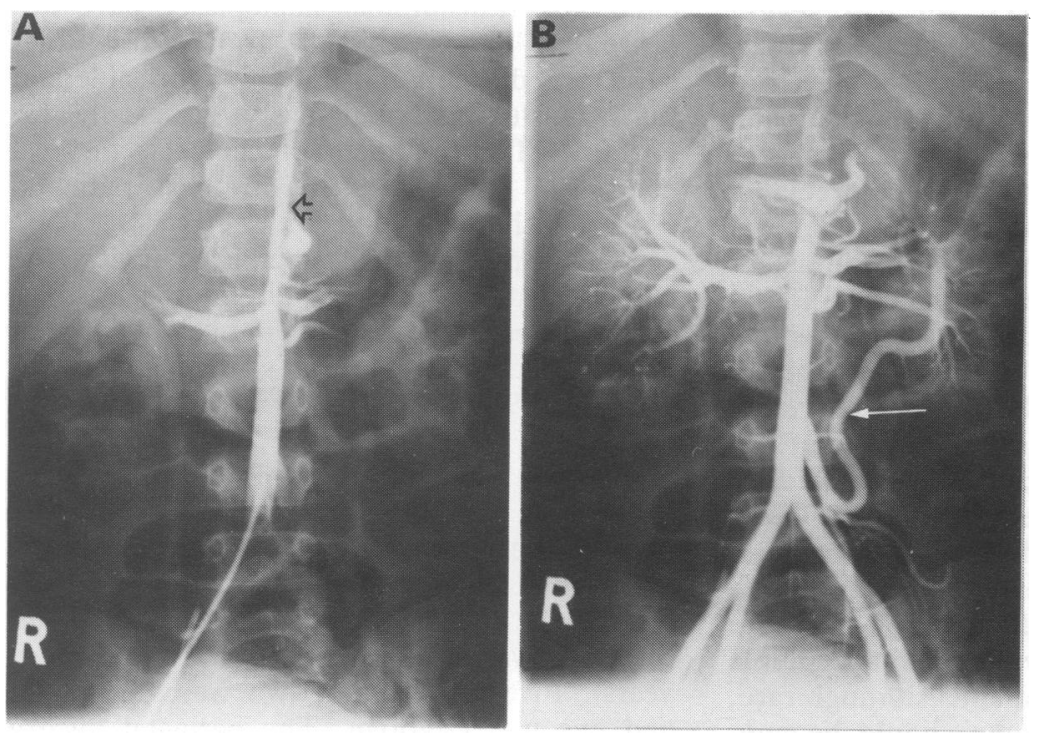

Figure 1 Case 4 aged 6. (A) There is severe narrowing of the abdominal aorta and stenosis of both the origin of the coeliac (open arrow) and the superior mesenteric arteries. (B) There is also an enlarged collateral from the inferior mesenteric artery (the 'wandering artery of Drummond') (white arrow).
The hyperuricaemia observed in the third patient with Williams' syndrome is unexplained: it was present before he was given bendrofluazide. Three had persistent eosinophilia, ranging from 780 to $1870 \times 10^{6} /$ litre. One (case 7 ) had a positive Mantoux test without a history of BCG immunisation, the significance of which is unknown: there was no other evidence of tuberculosis. Case one had multiple congenital abnormalities: single umbilical artery, severe growth and developmental delay, flexion deformities of all limbs, microphthalmia with severe visual impairment, corneal clouding, sensorineural deafness, and microcephaly with dilated cerebral ventricles and cortical atrophy. Renal function at latest follow up was normal in three patients (cases 2, 3, and 5) with plasma creatinine concentration 70,54 , and $83 \mu \mathrm{mol} / 1$ respectively, reduced in cases 4 and 7 (113 and $143 \mu \mathrm{mol} / \mathrm{l})$, both of whom were receiving captopril, and unavailable in cases 1 and 8 (records lost) and case 6 (died).

\section{RADIOLOGICAL FINDINGS}

Aortography was performed via the percutaneous femoral approach in all patients. Originally, studies were with film but more recently, digital angiography has been used. Oblique views were obtained as necessary to demonstrate the origins of the renal arteries and mesenteric vessels. Follow up arteriograms were obtained in two patients (time intervals: case 2 of one year and case 4 of 10 years). Three patients additionally had examinations of the aortic arch. All patients had smooth segmental narrowing of the abdominal aorta over a variable distance (table 2). In five patients, this narrowing extended above the renal arteries. All eight patients had involvement of the renal arteries, bilaterally in seven. The superior mesenteric and coeliac arteries were affected in five patients. The inferior mesenteric artery was spared in all

Table 2 Radiological findings in MAS

\begin{tabular}{|c|c|c|c|c|c|c|c|c|}
\hline $\begin{array}{l}\text { Case } \\
\text { No }\end{array}$ & Aortic arch & Abdominal aorta & Renal & Coeliac & $\begin{array}{l}\text { Superior } \\
\text { mesenteric }\end{array}$ & $\begin{array}{l}\text { Inferior } \\
\text { mesenteric }\end{array}$ & $\begin{array}{l}\text { External } \\
\text { iliac }\end{array}$ & $\begin{array}{l}\text { Repeat } \\
\text { study }\end{array}$ \\
\hline 1 & Not studied & $\begin{array}{l}\text { Very narrow from } \\
\text { diaphragm to } \\
\text { bifurcation }\end{array}$ & Narrowed & Not seen & Narrowed & Not seen & Not seen & Not done \\
\hline 2 & $\begin{array}{l}\text { Abnormal vertebrals } \\
\text { with extensive } \\
\text { collaterals }\end{array}$ & $\begin{array}{l}\text { Diffusely narrowed } \\
\text { at level of renal } \\
\text { arteries }\end{array}$ & $\begin{array}{l}\text { 2R:both stenosed, } \\
\text { 2L:normal }\end{array}$ & Normal & Normal & Normal & $\begin{array}{l}\text { L:occluded, } \\
\text { R:narrowed }\end{array}$ & Yes \\
\hline 3 & Normal & $\begin{array}{l}\text { Irregular narrowing } \\
\text { from diaphragm to } \\
\text { just above origin of } \\
\text { superior mesenteric } \\
\text { artery }\end{array}$ & $\begin{array}{l}\text { Both stenosed with } \\
\text { poststenotic } \\
\text { dilatation }\end{array}$ & Occluded & Occluded & Enlarged & Normal & Not done \\
\hline 4 & Normal & Narrowed T11-L2 & $\begin{array}{l}\text { 3L:all narrowed, } \\
\text { IR:narrowed }\end{array}$ & $\begin{array}{c}\text { Narrowed } \\
\text { origin }\end{array}$ & $\begin{array}{c}\text { Narrowed } \\
\text { origin }\end{array}$ & Enlarged & Normal & Yes \\
\hline 5 & Not studied & $\begin{array}{l}\text { Diffuse tubular } \\
\text { narrowing of whole } \\
\text { abdominal aorta, } \\
\text { extending supra-renally }\end{array}$ & $\begin{array}{l}\text { Bilateral proximal } \\
\text { stenosis }\end{array}$ & Normal & Normal & Normal & Normal & Not done \\
\hline 6 & Not studied & Narrowed T12-L2 & Narrowed origins & $\begin{array}{l}\text { Severe stenosis } \\
\text { of origin with } \\
\text { poststenotic } \\
\text { dilatation }\end{array}$ & $\begin{array}{l}\text { Severe stenosis } \\
\text { of origin }\end{array}$ & Enlarged & Normal & Not done \\
\hline 7 & $\begin{array}{l}\text { Stenosis of right } \\
\text { subclavian }\end{array}$ & $\begin{array}{l}\text { Dilated segment above } \\
\text { slight narrowing at } \\
\text { level of renal } \\
\text { arteries }\end{array}$ & $\begin{array}{l}\text { 2R:both narrowed, } \\
\text { 2L:one normal, } \\
\text { one occluded, } \\
\text { intrarenal stenoses }\end{array}$ & Occluded & Occluded & Enlarged & Normal & Not done \\
\hline 8 & Not studied & $\begin{array}{l}\text { Diffuse tubular } \\
\text { narrowing at level } \\
\text { of renal arteries }\end{array}$ & $\begin{array}{l}\text { 2L:larger stenosed, } \\
\text { smaller normal, } \\
\text { IR:proximal stenosis } \\
\text { with poststenotic } \\
\text { dilatation }\end{array}$ & Normal & Normal & Normal & Normal & Not done \\
\hline
\end{tabular}



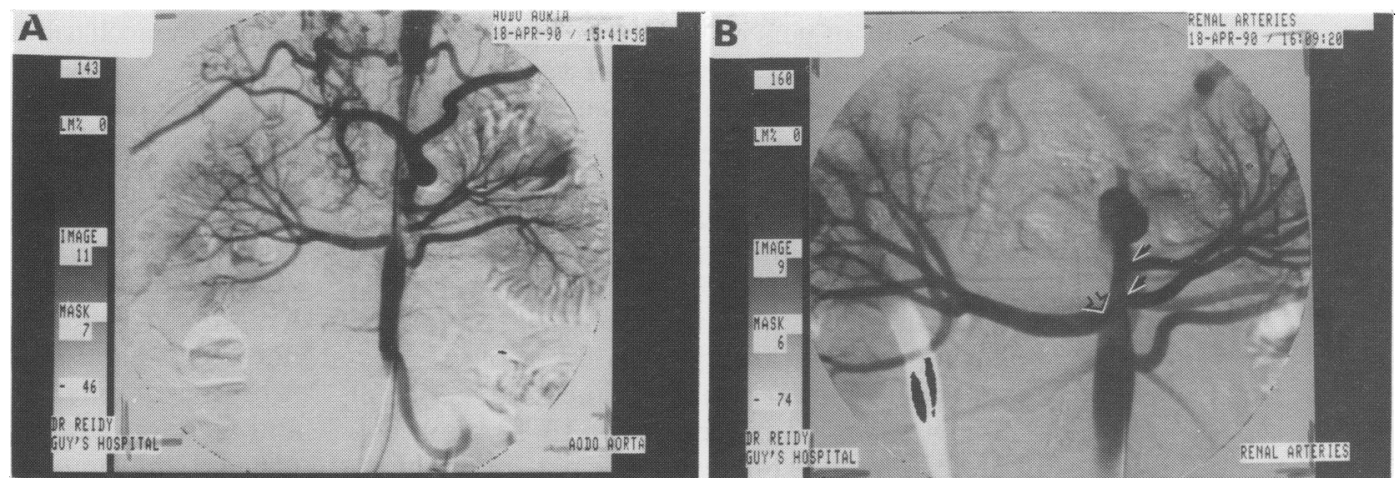

Figure 2 Case 4 aged 16. (A) There has been no significant change in appearance. (B) The stenosis of the proximal two of the three left renal arteries at their origin (solid arrows) and the slight narrowing of the origin of the single right renal artery (open arrow) are more clearly seen.

cases. Only one patient (case 2) had an abnormality of the iliac arteries (table 2): he also had abnormal vertebral arteries with extensive collateral formation and a subsequent angiogram a year later showed some progression of his iliac artery lesions. In contrast, the other patient studied twice (case 4) showed no change to his extensive disease in the 10 years that separated the studies (figs 1 and 2). Arch aortography was normal in case 3 but showed narrowing of the right subclavian artery in case 7 . The appearances on abdominal aortography were almost identical in cases 3 and 6 , as shown in figs 3 and 4 respectively. A hypertensive crisis occurred in one patient (case 4) as a complication of arteriography and was controlled only with great difficulty. No other complications were seen.

\section{Treatment}

Percutaneous transluminal angioplasty was not attempted in any patient in the series. Two

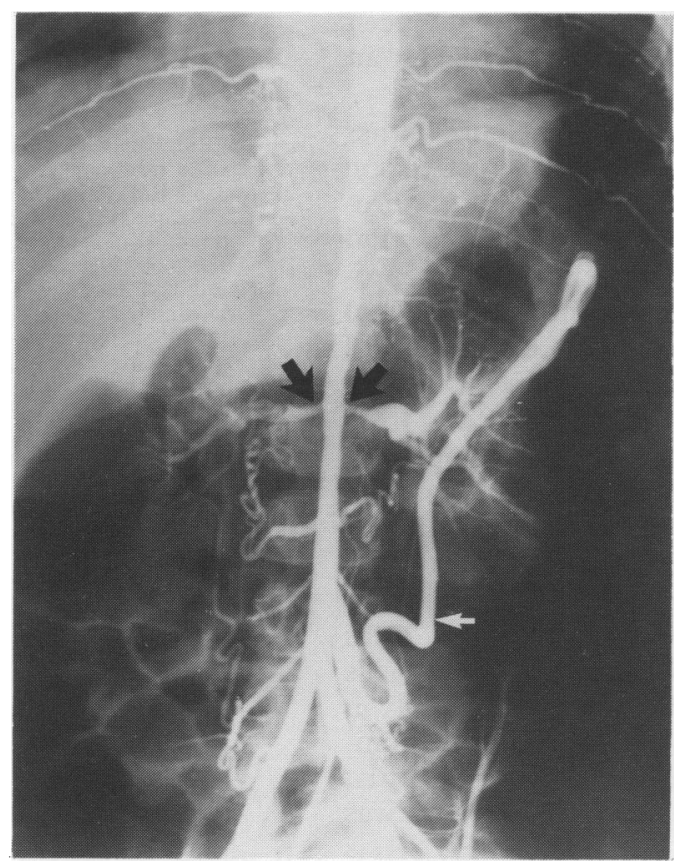

Figure 3 Case 3 aged 6. The abdominal aorta is severely narrowed. The coeliac and superior mesenteric arteries have not filled. There is enlargement of intercostal arteries and collaterals from the inferior mesenteric artery (white arrow). There is also stenosis of the origin of both renal arteries with poststenotic dilatation (black arrows). patients were operated on. One (case 3) was successfully treated at 6.8 years of age with a thoracic aorta to aortic bifurcation Dacron bypass graft and bilateral autotransplantation of both kidneys. She remains normotensive 21 months after operation. The other (case 6), aged 12.4 years at the time of operation, died of Gram negative sepsis and massive bleeding five days after having a left renal autotransplant and a right iliorenal saphenous vein bypass graft. Surgery was not attempted in the other six patients because their lesions were considered technically inoperable and/or because medical control of hypertension was satisfactory. Medical treatment with combinations of two to six antihypertensive drugs was given to seven patients with moderate to good control of the blood pressure. The antihypertensive policy used varied somewhat over the period of the

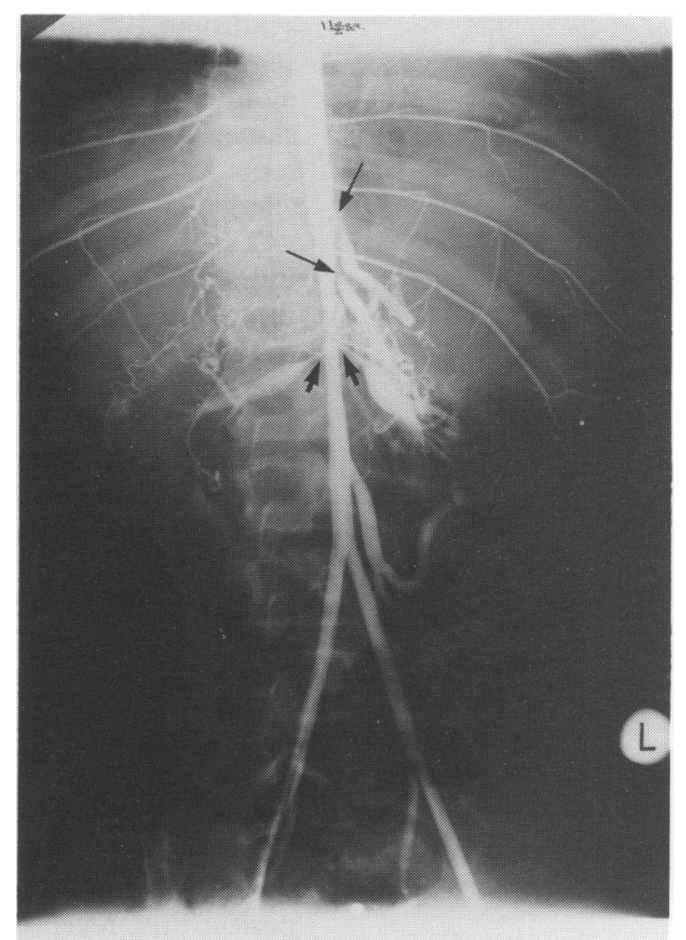

Figure 4 Case 6 aged 12. The appearances are almost indistinguishable from those of case 3 ( fig 3 ). There is again narrowing of the abdominal aorta. The origins of both renal arteries are stenosed with poststenotic dilatation (thick arrows). There is stenosis of the origins of the coeliac and superior mesenteric vessels (thin arrows) with collateral formation from the inferior mesenteric artery. 
study, but in general a diuretic was prescribed first, and if satisfactory control was not achieved with the maximum recommended dose other drugs were added; usually in the following order: first a $\beta$-adrenergic blocker, second a vasodilator, and finally an angiotensin converting enzyme inhibitor. The combinations and dosages varied within each patient over time: the drugs listed in table 1 are those prescribed during the most difficult period of blood pressure control in each patient. The mean period of follow up was 40 months (range 13-127 months). After 13 months follow up, one patient gradually became normotensive without antihypertensive drug treatment. Complications of drug treatment included minoxidil induced hirsutism in two and reversible, dose dependent, captopril induced impairment of renal function in one.

\section{Discussion}

MAS is an uncommon condition that can cause severe hypertension with its attendant risk of life threatening complications. The disease should be suspected in any young, severely hypertensive patient in whom renal and endocrine causes of hypertension have been excluded by routine investigations, and especially if abdominal bruits, eosinophilia of unknown origin, or Williams' syndrome are present. Poor volume peripheral pulses, although a pointer to the diagnosis, were found in only two of our patients and they cannot be differentiated from the findings in coarctation of the aortic arch which is more common in this age group. ${ }^{78}$ Systemic hypertension secondary to diffuse narrowing of the abdominal aorta has been reported previously in patients with Williams' syndrome, ${ }^{10}$ and the findings in our patients suggest that this association occurs more commonly than would be predicted by chance alone. Appreciable eosinophilia has not been reported before in MAS, and might suggest an allergic or immunological aetiology.

The differential diagnosis includes other important causes of renovascular hypertension in children such as Takayasu's arteritis, fibromuscular dysplasia, neurofibromatosis, and mucopolysaccharidoses. Patients with neurofibromatosis may have stenosis of the abdominal aorta and its branches including the renal arteries but the disease does not affect the aorta and the lesions differ angiographically from those of MAS, ${ }^{11}$ as do those of. fibromuscular hyperplasia. ${ }^{12-14}$ The differentiation between MAS and Takayasu's arteritis may be difficult: clear criteria for separating the two do not exist. Nevertheless, it is worthwhile attempting to make the distinction as anti-inflammatory drugs may be useful in some patients with Takayasu's disease. The latter condition occurs primarily in young women with associated rheumatic complaints including arthritis, myalgia, pleuritis, pericarditis, fever and rash, none of which was present in any of our patients. The ESR is usually raised. A mixed type of segmental involvement of arteries is often present and the disease is very uncommon in non-oriental populations. ${ }^{2} 1516 \mathrm{An}$ arteriopathy very similar to that of MAS has recently been described in mucopolysaccharidoses $1 \mathrm{H}$ (Hurler's syndrome) and $1 \mathrm{~S}$ (Scheie's syndrome). ${ }^{17}$ None of our cases had features suggestive of any form of mucopolysaccharide storage disorder.

Aortography is the only investigation diagnostic for MAS. From our own experience and that of others, it is recommended that aortography should be performed in all severely hypertensive patients in whom the diagnosis has not been established from initial renal imaging (ultrasonography, radionuclide scintigraphy, and excretory urography), plasma renin activity, plasma aldosterone, and urine and plasma catecholamine estimation. ${ }^{18}{ }^{19}$ Meticulous blood pressure control must be maintained during and after arteriography: a hypertensive emergency occurred in one of our patients.

The choice of antihypertensive drugs is not different from that conventionally used in renovascular and other severe forms of hypertension. Most patients in the present series responded well to captopril combined with a diuretic and/or a vasodilator and/or a $\beta$-adrenergic blocker. Renal function should be closely monitored in all patients receiving an inhibitor of angiotensin converting enzyme.

The indications for surgery in MAS have not been established. Surgical mortality is high due to the extensive nature of the vascular abnormality and the difficulty in fashioning an appropriate graft. Percutaneous transluminal angioplasty has not been reported to be followed by long term success in MAS. ${ }^{2}$ Most of our patients have done well on medical treatment alone. In general, we recommend that surgery be reserved for those in whom medical control of blood pressure is unsatisfactory or associated with intolerable side effects, and in whom the disease is judged to be amenable to surgical correction without an unacceptable level of operative risk.

1 Sen PK, Kinare SG, Engineer SD, Parulkar GB. The middle aortic syndrome. Br Heart $\mathcal{f}$ 1963;25:610-8.

2 Messina LM, Goldstone J, Ferrell LD, Reilly LM, Ehrenfeld WK, Stoney RJ. Middle aortic syndrome: effectiveness and durability of complex arterial revascularization techniques. Ann Surg 1986;204:331-7.

3 Nanni GS, Hawkins IF Jr, Alexander JA. Percutaneous transluminal angioplasty of an abdominal aortic coarctation. AfR 1983;140:1239-41.

4 Graham LM, Zelenock GB, Erlandson EE, Coran AG, Lindenauer SM, Stanley JC. Abdominal aortic coarctation and segmental hypoplasia. Surgery 1979;86:519-28.

5 Gupta S. Surgical and haemodynamic considerations in middle aortic syndrome. Thorax 1979;34:470-8.

6 Lewis VD III, Meranze SG, McLean GK, O'Neill JA Jr, Berkowitz HD, Burke DR. The midaortic syndrome: diagnosis and treatment. Radiology 1988;167:111-3.

7 Gersony WN. Coarctation of the aorta. In: Behrman RE, Vaughan VC III, eds. Nelson textbook of pediatrics. 13th Ed. Philadelphia: Saunders, 1987:993-5.

8 Dillon MJ. Clinical aspects of hypertension. In: Holiday MA, Barratt TM, Vernier RL, eds. Pediatric nephrology. 2nd Ed. Baltimore: Williams and Wilkins, 1987:743-57.

9 Daniels SR, Loggie JMH, Schwartz DC, Strife JL, Kaplan S. Systemic hypertension secondary to peripheral vascular anomalies in patients with Williams' syndrome. 7 Pediatr 1985;106:249-51.

10 Maisuls $\mathrm{H}$, Alday LE, Thüer $\mathrm{O}$. Cardiovascular findings in the Williams-Beuren syndrome. Am Heart $\mathcal{f}$ 1987;114: 897-9.

11 Halpern M, Currarino G. Vascular lesions causing hypertension in neurofibromatosis. $N$ Engl $\mathcal{f}$ Med 1965;273: 248-52.

12 Harrison EG Jr, Hunt JC, Bernatz PE. Morphology of fibromuscular dysplasia of the renal artery in renovascular hypertension. Am $\mathcal{F}$ Med 1967;43:97-112.

13 Rushton AR. The genetics of fibromuscular dysplasia. Arch Intern Med 1980:140:233-6. 
14. Goncharenko V, Gerlock AJ Jr, Shaff MI, Hollitield JW. Progression of renal artery fibromuscular dysplasia in 42 patients as seen on angiography. Radiology 1981;139:45-51.

15 Schaller JG, Wedgwood RJ. Takayasu arteritis. In: Behrman RE, Vaughan VC III, eds. Nelson textbook of pediatrics. 13th Ed. Philadelphia: Saunders, 1987:530.

16 Haas A, Stiehm ER. Takayasu's arteritis presenting as pulmonary hypertension. Am $\mathcal{F}$ Dis Child 1986;140:372-4.

17 Taylor DB, Blaser SI, Burrows PE, Stringer DA, Clarke JTR, Thorner P. Arteriopathy and coarctation of the abdominal aorta in children with mucopolysaccharidosis: imaging findings. $A \mathcal{F R}$ 1991;157:819-23.

18 Stringer DA, de Bruyn R, Dillon MJ, Gordon I. Comparison of aortography, renal vein renin sampling, radionuclide scans, ultrasound and the IVU in the investigation of childhood renovascular hypertension. Br $\mathcal{F}$ Radiol 1984;57: 111-21.

19 Dillon MJ. Investigation and management of hypertension in children. A personal perspective. Pediatr Nephrol 1987;1: 59-68.

\section{Co-trimoxazole and life in the raw}

No matter how hard their lives may seem people have, in the

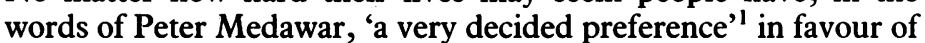
life for themselves and those they love. In the Jumla district of western Nepal life, it seems, is about as tough as it can get. It is a mountainous district with about 80000 people living at a height of 8 or 9000 feet in a cold, dry climate with no roads, poor housing, low literacy, inadequate food, no routine child health services, and nearly $20 \%$ of children dying in infancy. Nevertheless, despite an endemic fatalism about child deaths, one of the striking findings of a recent study (Mrigendra Raj Pandey and colleagues, Lancet 1991;338:993-7) was that mothers quickly learned to recognise pneumonia and bring their children for treatment.

For every 1000 people one was chosen to be the community health worker and that person was given nine days training, the aim being to teach them to recognise pneumonia in children under the age of 5 years and to treat it with a five day course of cotrimoxazole. The health workers travelled around their villages visiting families with young children every two weeks and actively seeking out cases of pneumonia diagnosed on the basis of tachypnoea and chest indrawing. In the first year of the study only $15 \%$ of cases were actively referred by the parents to the health worker but by the third year the proportion was $56 \%$. Pneumonia and diarrhoea accounted for over $60 \%$ of deaths in children less than 5 years old with pneumonia predominating under 6 months and diarrhoea after that.

The study lasted for three years and during that time the overall relative risk of death from all causes compared with that before the introduction of the treatment scheme fell from $0.87(95 \%$ confidence interval 0.73 to 1.03$)$ in the first year to $0.72(0.63$ to $0.82)$ in the third. The relative risk of death from pneumonia was $0.88(0.59$ to 1.32$)$ in the first year of the study and $0.70(0.50$ to $0.97)$ in the third and from diarrhoea it was $0.81(0.62$ to 1.07$)$ in the first year and $0.64(0.52$ to 0.77$)$ in the third. The health workers were given no training in the treatment of diarrhoea and the improvement in diarrhoeal death rate was attributed to better overall health and nutrition of the children consequent upon the treatment of pneumonia. By far the greatest reduction in mortality was in the second six months of life. In that age group the relative risk of death from all causes was $0.68(0.43$ to 1.08$)$ in the first year of the study and $0.36(0.24$ to 0.55$)$ in the third. In children between 1 and 5 years the effect was relatively disappointing (relative risk $1.02(0.76$ to 1.37$)$ in year 1 and $0.89(0.73$ to 1.09$)$ in year 3).

This study shows that uneducated local people can be taught to recognise and treat pneumonia in young children with a subsequent fall in infant mortality and the financial cost was small (less than US $\$ 4$ per child per year). Mothers soon learn to suspect pneumonia and respond to the provision of a service. Presumably the next step will be to teach them how to manage diarrhoea. 